Homepage: http://epubs.icar.org.in/ejournal/index.php/JWR

\title{
High-throughput Phenotyping for Abiotic Stress Resilience in Cereals
}

\author{
Nusrat Ul Islam ${ }^{1}$, Shabir Hussain Wani ${ }^{2 *}$, Gowhar Ali ${ }^{3}$, Zahoor Ahmad Dar ${ }^{4}$, Altaf Wani ${ }^{1}$ and Ajaz \\ Lone $^{4}$ \\ ${ }^{1}$ Division of Genetics and Plant Breeding, FoA, Wadura, Sopore, SKUAST-Kashmir, India \\ ${ }^{2}$ Mountain Research Centre for Field Crops, Khudwani,192101, Sher-e-Kashmir University of Agricultural Sciences and \\ Technology of Kashmir, JEKK, India, ORCiD: https://orcid.org/0000-0002-7456-4090 \\ ${ }^{3}$ National Seed Project, SKUAST-K, Shalimar, Srinagar, Jammu and Kashmir, India \\ ${ }^{4}$ Dryland Agriculture Research Station, Rangreth, SKUAST-Kashmir, India
}

\section{Article history:}

Received: 7 Jan., 2021

Revised: 27 March, 2021

Accepted: 30 April, 2021

\section{Citation:}

Islam NU, SH Wani, G Ali, ZA Dar, A Wani and A Lone. 2021. High-throughput Phenotyping for Abiotic Stress Resilience in Cereals. Journal of Cereal Research 13(1): 1-15. http://doi.org/10.25174/2582$\underline{2675 / 2021 / 111256}$

\section{"Corresponding author:}

E-mail: shabirhussainwani@gmail.com

(C) Society for Advancement of Wheat and Barley Research

\begin{abstract}
Around 70 percent of crop yield losses are projected because of climate induced abiotic stresses like moisture stress, soil salinity and heat stress. Critical to the stability of cropping systems in the face of climate change is the capacity to rapidly grow germplasm with tolerance to complex polygenic inherited abiotic and biotic stresses combined. Molecular breeding provides the means to speed up cereal breeding, but adequate phenotyping protocols are required to ensure that the much-anticipated benefits of novel breeding tools can be realized. Tremendous advances in phenomics have taken place in the recent past. Both forward and reverse phenomics have developed to help determine either the best genotype with the desired feature or mechanism and the genes that make the genotype the best. High-throughput phenomics studies include techniques for screening substantial germplasm sets for a specific trait using high-throughput phenotyping (HTP) technologies like advanced robots, high-tech sensors, 3D imaging, fluorescence imaging, NIR imaging, lemnatec, etc. The high velocity of plant phenotyping based on phenomics accelerates the selection phase of potential advanced germplasm resilient towards climate induced stresses.
\end{abstract}

Key words: Abiotic stress Resilience, Forward and reverse phenomics, High-throughput phenotyping Phenomics

\section{Introduction}

By 2050, the world's population is projected to hit 9 billion and the current production of food must be doubled to meet the needs of a rising population (Tester and Langridge, 2011, Ganie et al., 2021). Currently, intermittent precipitation events, high temperatures, drought, salinity stress, etc. are more likely to occur due to global climate change, which has increased the pace of biotic and abiotic stresses (Wani et al., 2018; Atif et al., 2019). In turn, these biotic and abiotic stresses pose a deteriorating risk to crop yield and quality, making it difficult to resolve the global food challenge (Pereira,
2016, Wani et al., 2021). Cereal crops such as Wheat are grown under rainfed conditions due to which they become more prone to abiotic stresses. Hence in-depth knowledge and mechanisms involved in drought effect on wheat metabolism is vital for evolving drought-tolerant wheat varieties (Itam et al., 2020). To overcome these potential challenges of climate change, the production of elite germplasm can deal with abiotic stresses or the development of climate-smart germplasm will be a priority (Leakey et al., 2009; Ziska and Bunce, 2007; Wani et al., 2020a). The yield potential and stability of a genotype are 
important for increasing crop production. Development of genotype having tolerance to abiotic stresses is a key factor in crop output stability (Furbank and Tester, 2011, Azhar et al., 2020; Kumar et al., 2021). A researcher must thoroughly analyze the response in terms of phenotypic changes and the processes that control the response of a plant under stressed conditions in order to determine the ability of a given genotype under a specific abiotic stress (Mickelbart et al., 2015).

In genomics, considerable progress has been made, especially the rapid developments in next generation sequencing (NGS) technologies or molecular breeding approaches such as marker assisted breeding (MAB), marker assisted backcross (MABC) or marker assisted recurrent selection (MARS), etc., to improve crop varieties that show tolerance to stress conditions (Varshney et al., 2014; Wani, 2019; Wani et al., 2020b). However, there is a substantial gap between genomic knowledge and its use in practical crop improvement, and the most important reason is that accurate and high-performance phenotyping tools are not usable, leading to poor gene/QTL results for genomics-assisted breeding (Varshney et al., 2012; Choudhary et al., 2019; Gosal et al., 2020).

The new age of phenomics has provided scientists with the tools to unlock the data coded in plant genomes (Finkel, 2009; Yang et al., 2020). The high speed of plant phenotyping based on phenomics and its ability to produce full sets of field data have accelerated the selection phenomenon potential elite advanced lines that execute well during stress conditions (Montes et al., 2007). An allinclusive tactic to plant phenotyping helps to polish our awareness of environmental-influenced characteristics. The advanced tools presented by phenomics allow scientists to categorize germplasm with abiotic stress tolerance effectively.

\section{HTP platforms used for phenotyping abiotic stress resilience related traits}

In several institutions around the world, a large range of fully automated high-throughput phenotyping systems are available based on non-destructive measurements (Furbank and Tester, 2011). By using high-tech automated sensors, imaging devices, and computing resources, HTP platforms accelerate phenotyping (Furbank, 2009; Yang et al., 2020). The HTP platforms include imaging techniques viz.,3-D imaging, near infrared imaging, far infrared imaging, flourescence imaging, visible light scanning, hyperspectral imaging, magnetic resonance imaging and positron emission tomography, lemnatec technology, phenonet, phenomobile, dunken technologies MS31000 imager, phenocopter, helium-filled aerostats and phenotower (Rahman et al., 2015).

These systems include clear imaging features, mechanical transport for the mobility of imaging plants, efficient imaging formulas and data analytics (Gerke et al., 2009). These HTP platforms have emerged as advanced plant phenotyping tools integrated with advanced software systems (Paproki et al., 2012).

\section{$2.13 D$ (Three-Dimensional) Imaging}

$3 \mathrm{D}$ plant images are obtained by employing many cameras connected by a computer package to capture multiple images from various angles (Weirman, 2010). It is used to calculate the number of leaves, form, angle, colour, health of the leaf, tiller number, mass of the shoot, etc. For 3D imaging and mapping in plants, two methods are most widely used; foremost, laser imaging detection and ranging (LIDAR) techniques that image a act (Omasa $e t$ al., 2007) and, secondly, stereo photography by means of more than two cameras (Biskup et al., 2007).

For QTL mapping, Topp et al. (2013) used semi-automated $3 \mathrm{D}$ imaging and digital phenotyping to classify core regions of the root architecture managed by the rice genome. It has been used in Arabidopsis thaliana to calculate yield characteristics, root architecture, imbibition, germination rates, etc. under drought stress (Woo et al., 2008).

\subsection{Far-infrared Imaging}

FIR imaging is used either inside the leaves of one plant or between different plants to calculate temperature differences. FIR imaging can also be used to detect plants with cool canopies in the fields (Leinonen and Jones, 2004). FIR cameras can also calculate changes in stomatal conductance so that the photosynthesis rate can be calculated (Wang et al., 2004). Differences in temperature is used to calculate photosynthetic behavior, salinity tolerance and efficient quality of water usage (Lafitte et al., 2003).

With the upsurge in canopy temperature of a shrub with mounting salt levels, FIR imaging has been used to screen a number of plant varieties for salinity stress resilience in barley (Sirault et al., 2009). So, the canopy of plants 
that can sustain lower temperatures when imaged in the presence of salt with the FIR camera is extra salt resilient and thus grows well in high saline soils. By means of highvelocity imaging with FIR, Salt tolerance can be assessed at the stage of seedlings as well (Cook et al., 2012).

\subsection{Near-infrared imaging}

Infrared thermal imaging enables the imaging of infrared radioactivity released from the target by visualization. For imaging, this machinery uses inner molecular motions of substances emitting infrared radiation (Kastberger and Stachl, 2003). Infrared imaging is conducted at two unique wavelength ranges of light, one at a near-infrared (NIR) range of $0.9-1.55 \mu \mathrm{m}$ and another at a far-infrared (Far-IR) wavelength range of 7.5-13.5 $\mu \mathrm{m} . \mathrm{NIR}$ ) imaging is used to monitor leaf and soil water content and motion, while far-infrared (FIR) cameras are used to study temperature (Weirman, 2010) .The NIR calculation of the soil is performed to determine the rate of absorption of water by the roots. NIR imaging is employed in seed kernels to analyze the amount of starch present in leaves in addition to oil and protein (Jones et al., 2009). NIR has been used to test for drought stress germplasms such as rice and soybeans (Seelig et al., 2008). NIR quantifies characteristics associated with osmotic resistance under salinity stress in wheat and barley, e.g. (Lobet et al., 2011).

\subsection{Fluorescence imaging}

Fluorescence imaging is an effective technique for plant stress determination. The photosynthetic apparatus is connected to chlorophyll fluorescence and these measurements help track and calculate how plants and leaves react to biotic and abiotic stress (Meroni et al., 2009). Fluorescence can be used to research simple chlorophyll emission through pulse amplitude-modulated (PAM) fluorescence to evaluate photosystem II behavior. Fluorescence imaging has also been used to study drought responses under controlled environments (Woo et al., 2008). Investigates photosynthetic performance under stressful environments e.g in wheat, tomato (Jansen et al., 2009). Increase in the chlorophyll fluorescence ratios depict the stress induced decrease in chlorophyll content and are very early stress indicators (Lichtenthaler et al., 1996).

\subsection{Visible Light (Monochromatic or Color) Imaging}

Visible light imaging operates at a wavelength of between 400 and $700 \mathrm{~nm}$. Digital cameras can use two-dimensional
(2D) images to examine shot biomass, yield attributing characters (Duan et al., 2011), leaf structure (Bylesjo et al., 2008), panicle features (Ikeda et al., 2010) and root traits (Ikeda et al., 2010). During green stage, rosette plants are usually photographed from the tip (Jansen et al., 2009). Moller et al. (2007) used thermal and visible imaging to estimate the status of irrigated grapevines in crop water. Three-dimensional imaging has been developed for the rice root system along with the software framework (RootReader3D).

Using a 3D digitizer and L-system formalism,' 3D virtual rice' was developed to demonstrate the differences in structure and development between cultivars and under different environmental conditions. (Watanabe et al., 2005). The color data gives an estimate of the degree of senescence. Senescence during drought of older leaves suggests escape or avoidance. It is possible to distinguish stay-green genotypes that could continue photosynthesis under water stress (Foulkes et al., 2007).

\subsection{Hyperspectral Imaging}

The continuous spectrum in the entire visible and NIR region is used in hyperspectral imaging and is used for more complex studies of various forms of pigmentation, water, biochemical compositions, and Vis. The proportion of light reflected by non-transparent surfaces is spectral reflectance. To detect plants stressed by salty soil or drought, researchers use this spectral reflectance long before it can be eye-catching (Bock et al., 2010). Under heat and drought stress it has been used to measure leaf and canopy temperature in rice and panicle health status in wheat (Dale et al., 2013).

\subsection{Positron emission tomography (PET)}

PET is a method which nondestructively images the dispersal of positron-emitting radionuclide-labelled compounds such as C-11, N-13 or Fe- 52 (Kiyomiya et al., 2011; Tsukamoto et al., 2009). It envisages the distribution and transport of metabolites labeled with elements of positron-emitting radionuclides therefore assists in the study of plant metabolism. In plants along a transport road. Buhler et al., 2011 proved transport velocity and lateral loss or photo assimilate. When used together with MRI and PET, both structural and functional characteristics can be analyzed simultaneously. PET has been used to visualize shoot to root translocation in sugar beet and radish under salinity stress, root architecture under heat stress in rice 
and wheat and phenology and physiology under drought stress in barley (Jahnke et al., 2009).

\subsection{Magnetic Resonance imaging (MRI)}

In order to take images, MRI includes a mixture of magnetic field and radio waves. It is widely adopted for imaging plant roots. By detecting nuclear resonance signals, MRI offers structural knowledge about inner physiological processes. The symptoms caused by cyst nematodes are visualized via MRI (Hillnhutter et al., 2012). It has also been used in stress conditions to assess the water content of rice, wheat and barley. It has also been used in many crops such as poplar, castor bean, tomato and tobacco to provide practical data such as water diffusion and transportation in plants (Windt et al., 2006)

\subsection{Lemna-Tec technology}

LemnaTec, a German company, has developed a highthroughput integrated phenotyping platform that includes the pipeline of imaging, automation of image processing and data handling modules. The platform has the capacity to easily measure almost unlimited sets of parameters, allow comprehensive screening and dynamically provide statistics on different plant characteristics. To measure plant height/width, biomass and plant architecture, these chambers offer top and side imaging of both plant roots as well as canopy (Mir et al., 2012).

Color, form, size and design research. Lemna Tec can significantly boost the precision and throughput of phenotyping, thereby helping to better elucidate the genetic regulation of complex characteristics of drought tolerance in plants. Bringing integrative phenotyping technology from controlled environments to the field, LemnaTec will improve the evaluation of plant responses to drought while allowing for high-throughput screening and comprehensive and accurate phenotypic data to be produced. In connection with high-through-put conveyor systems, Lemna-Tec has developed unique water management hardware and software tools to investigate how plants respond to drought stress at various time scales. It has been used in barley, tomato, corn, sorghum, Arabidopsis etc. under drought pressure and salt stress in barley, rice etc. (Araus and Cairns 2014).

\section{Phenonet}

Phenonet is the CSIRO model data logger for sensors such as the FIR thermometer, chlorophyll fluorescence sensors, soil moisture sensors, camera and weather station. It tests the temperature of the canopy and photosynthetic plant activity. It tracks changes in the climate across the field and continuous growth and growth of crops (Weirman, 2010)

\section{Phenomobile}

Phenomobile is a researcher-driven crop site vehicle fitted with digital cameras to estimate leaf greenness and ground cover, a far-infrared thermometer to assess canopy temperature, a 3D stereo imaging system to determine plant biomass. It flies at speeds of 3-5 km per hour through the field site and gathers dimensions of plot immediately below it and on both sides (White et al., 2012)

\section{Duncan Technologies MS3100 Imager}

Duncan Technologies MS3100 Imager provides three types of optical multi-spectral, infra-red and traditional cameras. It's put on a chopper. It photographs the canopy and, by taking 3D images, decides the biomass of the plant. Without a pilot, remote helicopters are a safer substitute to pilot-based aircraft because they permit flying at lesser altitudes and cost effective in operation (White et al., 2012).

\section{Phenocopter}

Phenocopter is a remote-controlled, gas powered model helicopter developed by Merz and Chapman in 2011 at CSIRO. It measures plant height, canopy cover, lodging and temperature. Fluorescence emissions are studied using hyperspectral and infrared cameras as a function of water stress (Tejada et al., 2009). Utilizing pilot less helicopter for thermal and narrowband multispectral remote sensing for foliage capturing has been demonstrated by (Berni $e t$ al., 2009).

\section{Helium-filled aerostats}

Helium-filled $2 \mathrm{~kg}$ payload aerostats, harbored with camera scan infrared or color images of a field 30 to $80 \mathrm{~m}$ above ground level (Weirman, 2010). Jensen $e t$ al., (2007) identified the use of an aerostat to track the feedback of wheat to nitrogen using digital cameras, using color and near-infrared images. In a cotton irrigation analysis, Ritchie et al. (2008) estimated evapotranspiration using data obtained by a two-camera system from the Normalized Difference Vegetation Index (NDVI).

\section{Phenotower}

The Phenotower holds infrared and reflectance sensors and is mounted on a trolley. It collects data on proportional 
canopy temperature, and ground cover among diverse germplasm at once, parallel to the vegetation (White et al., 2012). By collecting multi-spectral data for vegetation, nutrient and water status indices at a spatial resolution of $1 \mathrm{~m}$, it characterizes water and nitrogen stress for parcels (Haberland et al., 2010).

\section{Screening for Abiotic Stress Resilience Traits}

The main abiotic stresses that cause yield loss in agricultural crops worldwide are drought, salinity and temperature extremes. Phenotyping for resistance for such stresses is also a major task due to the complexity of governing systems responsible for tolerance for abiotic stresses (Vandenbroucke and Metzlaff, 2013). But with the ability of effective high-throughput phenotyping methods, it's easy to non-destructively characterize various traits for broad germplasm sets under drought and heat stress conditions and improve the genetic dissection of complex stress tolerance mechanisms by providing reliable and accurate phenotypic data (Yang et al., 2013).To record phenotypic deviations involves the use of sophisticated techniques to analyze the main parameters unique to stress, ensuing an accurate assessment of the phenotypic attribute. The degree of stress and extent of resistance or vulnerability of a cultivar has been assessed using a variety of parameters (Collins et al., 2008).

\subsection{Salinity Stress}

Phenotypically, the rejoinder of plants to elevated external points of $\mathrm{NaCl}$ is complex. The approaches adapted for phenotyping capture the behavior that reacts to salinity. In two different phases, a plant's responses to salinity stress occur (Munns and Tester, 2008): The initial step is the osmotic phase, that begins immediately after the proportion of salt rises to a grave level around the roots and contrarywise disturbs the plant development by reducing the growth of new leaves and hindering the initiation of young leaves. Growth rate fluctuations can be calculated by regular plant imaging and a drop in the plant development triggered by salinity stress can be recorded (Rajendran et al., 2009). Ion-specific response in the second phase is also called as tissue tolerance, that begins at an advanced phase when $\mathrm{Na}+$ or $\mathrm{Cl}$ amasses to lethal stages in the plant tissue, resulting to the untimely ageing of mature leaves. By means of color data of visible light imaging, the commencement and gradation of agedness can be measured to enable quantification of tissue tolerance in plants. A non-destructive approach has been developed by Rajendran et al. (2009) to phenotype crop salinity tolerance machineries by assessing osmotic tolerance and tissue tolerance with a Scanalyzer 3D using visible light imaging techniques. In contrast to osmoticsensitive plants, osmotic-tolerant plants display meager falls in comparative growth rate, which will show a severe reduction in growth when exposed to $\mathrm{NaCl}$ ( $\mathrm{Rahman}$ et al., 2015). Infrared thermography is an alternative method of calculating osmotic resistance. Stomatal conductance decreases down there by rising the temperature of the leaf because of salinity. Sirault et al. (2009) has established a phenotyping method based on this theory to quantify osmotic tolerance-related salt tolerance components for durum wheat and barley genotypes by using infrared thermography to measure leaf temperature. Recently, thermal imaging and Scanalyzer 3D designed by LemnaTec, has been considered as the best phenotyping technique to measure the various stresses including salinity stress in different crops and cereals and pulses as well (Dissanayake et al., 2020; Pineda et al., 2021; Song et al., 2021).

\subsection{Drought stress}

Drought tolerance is a dynamic characteristic that determines plant growth under moisture stress environments, which remains a difficult characteristic for breeders to manipulate (Cattivelli et al., 2008, Yang et al., 2020). Plants utilize numerous internal processes to deal with moisture stress, such as escape, tolerance, recovery, and avoidance (O'Toole and Chang, 1979). Germplasm having deep, coarse roots with profuse branching and penetration capacity, leaf rolling elasticity, primary stomatal closure and elevated cuticular tolerance are recorded as component characteristics of dryness prevention (Wang and Yamauchi, 2006). Leaf rolling, decrease in leaf area, condensed stem elongation rate, and lesser transpiration rate are among the early mechanisms of drought prevention (Reddy et al., 2003). For leaf area index measurement using digital infrared imaging, high-throughput phenotyping techniques are available (Shibayama et al., 2011, Yang et al., 2020).

The starting point for the development of root system modeling for different species of crops is unravelling of genetic differences for root system architecture. Several 
automated phenotyping structures are accessible to research root system architecture by means of visible, infrared or hyperspectral imaging due to advances made in the field of phenomics. Drought tolerance has been analyzed in cereal crops using advances phenomics tools including visible infrared imaging and thermal imaging (Negin and Moshelion, 2017; Badigannavar et al., 2018; Khadka et al., 2020)

Drought escape is alternative key phenomenon related to drought stress tolerance: by way of earliness in maturity and completion of growth period early to avoid late stress. Using visible imaging, flowering time can be easily tracked and genotypes may be phenotyped for their drought escape performance. The temperature of the canopy is an accurate and precise drought stress gauge. The most common technique used for visualizing temperature variations is Far-IR (also called IR thermal) imaging. Recently, thermal imaging technique was employed to measure the transpiration efficiency as a trait for drought stress tolerance in wheat (Abdelhakim et al., 2021). Infrared thermography for measuring plant's ability to tolerate stress conditions was also reported by Siddiqui et al., 2019.

\subsection{Heat/Cold Stress}

Temperature stress in plants occurs at higher places having chilling/freezing temperatures. Following heat stress, phenotypic and biochemical characteristics of cultivated plant species change, such as meagre germination ratio, less seedling development, abnormal seedling development, less seedling vigor and reduced development of radicles and plumules (Jagadish et al., 2016) and can be measured using MRI and PET. Therefore, based on the affected characteristics, the performance of adapted genotypes to heat or cold stress and the ability of crop varieties is recorded.

Structural vagaries due to heat stress comprise leaf, twig, branch, and stem scorching and sunburning, leaf ageing and fall off, shoot and root growth failure, fruit staining and permanent damage that can be quantified by visible light imaging to determine the resistant genotypes (Vasseur et al., 2014). The stay-green (SG) is a minor trait that permits crop plants to preserve their green leaves and photosynthesis ability for a lengthier time subsequent to anthesis, particularly under drought and heat stress environments. Therefore, SG plants have more grain- filling time and afterward more yield than non-SG (Kamal et al., 2019). In another study to characterize barley germplasm for heat stress various morphological traits were taken into consideration including days to flowering, grains per spike and yield per plot with further addition of physiological characteristics such as proline content, starch content and amino acid content (Sallam et al., 2018) The capacity of a genotype tolerate extreme temperature stress is strictly correlated with their capacity to scavenge ROS (Singh et al., 2020; Liu et al., 2021).

Among numerous abiotic stresses, low temperature stress disturbs plant growth and leads to considerable reduction in crop yields (Wani et al., 2016; Xie et al., 2020). Cold stress straightaway prevents metabolic responses and indirectly deteriorates the osmotic disparity, which decreases the elucidation of the determined inherent ability of plants, in comparison to heat stress. Low temperature is characterized as chilling stress $\left(<20^{\circ} \mathrm{C}\right)$ or freezing stress $\left(<0^{\circ} \mathrm{C}\right)$, together disturb plant growth via various phenomenons, depending on the temperature range whereas the quantity enzymatic rejoinders and membrane transport operations is reduced by chilling stress, freezing stress leads in creation of ice quartzes and membrane injury (Wang et al., 2020). By quantifying osmotic resistance, the infra-red imaging technique determines the low temperature resistant plants. Cold tolerance is related with physiological and biochemical modifications leading to transformed gene expression, bio membrane lipid composition and buildup of small molecules and can be quantified by imaging techniques such as MRI, PET and infra-red imaging.

\section{High Throughput Phenotyping (HTP) data analysis and management}

The large quantity and array of data attained with different techniques, its handling is the major challenge in phenotyping (Krajewski et al., 2015). HTP involves highly efficient computing and IT to measure as several parameters as possible. Because the data points generated are enormous and can't be managed manually, advanced approaches of data analysis are necessary from the initiation of raw data analysis till the results are validated (Kumar et al., 2020).

In conducting quantitation and data processing, the key bottleneck is the absence of elastic algorithms. Therefore, a high-throughput image analysis framework has been built 
to solve logistical and scalability problems, such as the bisque system from the Center for Bioimage Informatics, UC Santa Barbara (http://www.bioimage.ucsb.edu/). Billiau et al. (2012) have developed a "phenotyper" database on the principle of data warehouse to manage vast volumes of data from phenomics. Successful application of HTP platforms for use in drought, salinity and heat/ cold stress tolerance in plants, particularly cereal crops need capacity infrastructure for data management and analysis. (Shakoor et al., 2017; Li et al., 2021). The application of HTP for abiotic stress resilience in various cereal crops has been summarized (Table 1).

Table 1. Summary of Applications of High-throughput Phenotyping for Abiotic Stress Resilience in Cereal Crops

\begin{tabular}{|c|c|c|c|c|c|}
\hline $\begin{array}{l}\text { Plant } \\
\text { species }\end{array}$ & $\begin{array}{l}\text { Type of } \\
\text { stress }\end{array}$ & $\begin{array}{l}\text { Instrument/HTP } \\
\text { method }\end{array}$ & Traits measured & $\begin{array}{l}\text { Number of } \\
\text { genotypes studied }\end{array}$ & References \\
\hline \multirow[t]{5}{*}{ Rice } & Salt stress & $\begin{array}{l}\text { RGB imaging (multiple } \\
\text { views using LemnaTech }\end{array}$ & $\begin{array}{l}\text { Shoot biomass, shoot ion } \\
\text { concentration and shoot } \\
\text { senescence }\end{array}$ & $\begin{array}{l}2 \text { Indica rice cultivars } \\
\text { (IR64 and Fatmawati) }\end{array}$ & $\begin{array}{l}\text { Hairmansis et } \\
\text { al., } 2014\end{array}$ \\
\hline & $\begin{array}{l}\text { Drought } \\
\text { stress }\end{array}$ & $\begin{array}{l}\text { RGB imaging (multiple } \\
\text { views using LemnaTech }\end{array}$ & $\begin{array}{l}\text { Canopy temperature, Crop } \\
\text { biomass, crop greenness, } \\
\text { green projected area, plant } \\
\text { area/convex hull ratio }\end{array}$ & 533 rice accessions & Yang et al., 2015 \\
\hline & Salt stress & $\begin{array}{l}\text { RGB imaging (multiple } \\
\text { views using LemnaTech }\end{array}$ & $\begin{array}{l}\text { Loci detection for salinity } \\
\text { tolerance, relative growth } \\
\text { rate, transpirational rate and } \\
\text { transpiration use efficiency }\end{array}$ & $\begin{array}{l}2 \text { rice populations Aus } \\
\text { ( } 257 \text { accessions) and } \\
\text { Indica ( } 297 \text { accessions) }\end{array}$ & $\begin{array}{l}\text { Tamimi et al., } \\
2016\end{array}$ \\
\hline & $\begin{array}{l}\text { Drought } \\
\text { stress }\end{array}$ & $\begin{array}{l}\text { RGB imaging } \\
\text { fluorescence using } \\
\text { LemnaTech }\end{array}$ & $\begin{array}{l}\text { Projected plant area, plant } \\
\text { color, convex hull area, } \\
\text { plant water content, plant } \\
\text { temperature and eccentricity }\end{array}$ & $\begin{array}{l}20 \text { wild type plants, } 20 \\
\text { mutant }(\text { Osphyb }) \text { plants }\end{array}$ & Kim et al. 2020 \\
\hline & Salt stress & $\begin{array}{l}\text { Thermal imaging using } \\
\text { FLIR-SC- } 620\end{array}$ & $\begin{array}{l}\text { Leaf temperature, RWC, } \\
\text { stomatal conductance and } \\
\text { performance index }\end{array}$ & $\begin{array}{l}\text { Randomly selected } \\
\text { rice seeds from which } \\
26 \text { randomly selected } \\
\text { leaves were studied, } \\
6 \text { for RWC } 20 \text { for } \\
\text { stomatal conductance }\end{array}$ & $\begin{array}{l}\text { Siddiqui } \text { et al., } \\
2014\end{array}$ \\
\hline \multirow[t]{5}{*}{ Barley } & Salt stress & $\begin{array}{l}\text { RGB imaging (multiple } \\
\text { views using plant } \\
\text { accelerator }\end{array}$ & $\begin{array}{l}\text { Shoot biomass, shoot ion } \\
\text { concentration }\end{array}$ & 377 barley accessions & $\begin{array}{l}\text { Saade } e t \\
\text { al.,2020 }\end{array}$ \\
\hline & $\begin{array}{l}\text { Drought } \\
\text { stress }\end{array}$ & $\begin{array}{l}\text { RGB imaging (multiple } \\
\text { views), Hyperspectral } \\
\text { imaging using } \\
\text { LemnaTech }\end{array}$ & $\begin{array}{l}\text { Leaf length, leaf water } \\
\text { content, biomass } \\
\text { accumulation }\end{array}$ & 18 genotypes & Chen et al 2014 \\
\hline & $\begin{array}{l}\text { Drought } \\
\text { stress }\end{array}$ & $\begin{array}{l}\text { RGB imaging (multiple } \\
\text { views using LemnaTech }\end{array}$ & $\begin{array}{l}\text { Plant biomass, projected } \\
\text { shoot area, relative growth } \\
\text { rate, caliper length, height, } \\
\text { tiller number, plant height } \\
\text { and water use efficiency }\end{array}$ & 47 barley genotypes & $\begin{array}{l}\text { Honsdorf et } \\
\text { al.,2014 }\end{array}$ \\
\hline & $\begin{array}{l}\text { Drought } \\
\text { stress }\end{array}$ & Fluorescence imaging & $\begin{array}{l}\text { Plant architecture, yield } \\
\text { related traits, convex hull } \\
\text { geometry and chlorophyll } \\
\text { intensity. }\end{array}$ & $\begin{array}{l}95 \text { RILs and } 2 \text { parental } \\
\text { genotypes }\end{array}$ & $\begin{array}{l}\text { Mickolajczak et } \\
\text { al., } 2020\end{array}$ \\
\hline & $\begin{array}{l}\text { Oxidative } \\
\text { stress }\end{array}$ & Fluorescence imaging & $\begin{array}{l}\text { Seminal root length, leaf } \\
\text { necrosis, leaf classical viability } \\
\text { and relative root length }\end{array}$ & 11 barley genotypes & $\begin{array}{l}\text { Wang et al., } \\
2019\end{array}$ \\
\hline Maize & $\begin{array}{l}\text { Drought } \\
\text { stress }\end{array}$ & $\begin{array}{l}\text { Hyperspectral imaging } \\
\text { using PHENOVISION }\end{array}$ & $\begin{array}{l}\text { Root characteristics, anthesis } \\
\text { silking interval, drought } \\
\text { tolerance index and yield }\end{array}$ & 400 genotypes & $\begin{array}{l}\text { Mertens et al., } \\
2021\end{array}$ \\
\hline
\end{tabular}




\begin{tabular}{|c|c|c|c|c|c|}
\hline & Cold stress & $\begin{array}{l}\text { RGB imaging (multiple } \\
\text { views using plant } \mathrm{CV} \\
\text { software }\end{array}$ & $\begin{array}{l}\text { Shoot height, shoot area, leaf } \\
\text { necrosis }\end{array}$ & 40 maize genotypes & $\begin{array}{l}\text { Enders } \text { et al., } \\
2019\end{array}$ \\
\hline & $\begin{array}{l}\text { Drought } \\
\text { stress }\end{array}$ & $\begin{array}{l}\text { Unmanned ariel vehicle } \\
\text { imagery }\end{array}$ & $\begin{array}{l}\text { Green leaf area index (GLAI) } \\
\text { Dynamics }\end{array}$ & 400 genotypes & $\begin{array}{l}\text { Blancon et al., } \\
2019\end{array}$ \\
\hline & $\begin{array}{l}\text { Drought } \\
\text { stress }\end{array}$ & $\begin{array}{l}\text { Terrestrial lidar using } \\
\text { FARO Focus }{ }^{3 \mathrm{D}} \mathrm{X} 120 \\
\text { laser scanner }\end{array}$ & $\begin{array}{l}\text { Plant height plant area index, } \\
\text { projected leaf area }\end{array}$ & 20 maize varieties & Su et al.,2019 \\
\hline & Cold stress & Hyperspectral imaging & $\begin{array}{l}\text { Spectral reflectance values } \\
\text { and effective wave lengths of } \\
\text { plants }\end{array}$ & 60 genotypes & Xie et al.,2017 \\
\hline & $\begin{array}{l}\text { Water } \\
\text { stress }\end{array}$ & $\begin{array}{l}\text { Thermal imaging using } \\
\text { Midas 320L infrared } \\
\text { camera }\end{array}$ & $\begin{array}{l}\text { Canopy temperature crop } \\
\text { water stress index chlorophyll } \\
\text { index NDVI, biomass and } \\
\text { yield }\end{array}$ & 92 genotypes & $\begin{array}{l}\text { Romano et al. } \\
2011\end{array}$ \\
\hline \multirow[t]{6}{*}{ Wheat } & Salt stress & $\begin{array}{l}\text { Hyperspectral imaging } \\
\text { using LemnaTech }\end{array}$ & $\begin{array}{l}\mathrm{Na}^{+} \text {ion uptake, } \mathrm{K} / \mathrm{Na}^{+} \text {ratio, } \\
\text { root biomass and harvest } \\
\text { index }\end{array}$ & 4 wheat genotypes & $\begin{array}{l}\text { Moghimi et } \\
\text { al.,2018 }\end{array}$ \\
\hline & $\begin{array}{l}\text { Drought } \\
\text { stress }\end{array}$ & $\begin{array}{l}\text { Thermo-imaging } \\
\text { using self-construction } \\
\text { semiautomated }\end{array}$ & $\begin{array}{l}\text { MSALR Transcript level, } \\
\text { ALR Enzyme activities, } \\
\text { shoot surface area and shoot } \\
\text { biomass }\end{array}$ & $\begin{array}{l}3 \text { transgenic wheat } \\
\text { genotypes } 1779 \\
\text { immature embryos }\end{array}$ & $\begin{array}{l}\text { Feher juhasz et } \\
\text { al., } 2014\end{array}$ \\
\hline & Salt stress & $\begin{array}{l}\text { Plant Eye 3D Laser } \\
\text { scanner }\end{array}$ & $\begin{array}{l}\text { Plant height, number of } \\
\text { leaves, total leaf area and } \\
\text { fresh biomass }\end{array}$ & 80 plants & $\begin{array}{l}\text { Maphosa et al., } \\
2016\end{array}$ \\
\hline & $\begin{array}{l}\text { Drought } \\
\text { and heat } \\
\text { stress }\end{array}$ & $\begin{array}{l}\text { X-ray computed } \\
\text { tomography }\end{array}$ & $\begin{array}{l}\text { Seed shriveling, grain } \\
\text { deformation, total seed } \\
\text { weight/ear, seed number/ear, } \\
\text { single seed weight, seed shape } \\
\text { and seed surface area }\end{array}$ & $\begin{array}{l}315 \text { bread wheat } \\
\text { accessions }\end{array}$ & $\begin{array}{l}\text { Schimdt et al., } \\
2020\end{array}$ \\
\hline & $\begin{array}{l}\text { Drought } \\
\text { stress }\end{array}$ & $\begin{array}{l}\text { Hyperspectral } \\
\text { sensing aerial based } \\
\text { multispectral sensing }\end{array}$ & $\begin{array}{l}\text { Water band index, plant } \\
\text { biomass }\end{array}$ & 32 wheat genotypes & Yu et al.,2020 \\
\hline & $\begin{array}{l}\text { Drought } \\
\text { stress }\end{array}$ & $\begin{array}{l}\text { Unmanned ariel vehicle } \\
\text { imagery }\end{array}$ & $\begin{array}{l}\text { Leaf chlorophyll content, leaf } \\
\text { rolling, dry biomass, NDVI } \\
\text { and QTL for NDVI }\end{array}$ & $\begin{array}{l}248 \text { elite durum wheat } \\
\text { accessions }\end{array}$ & $\begin{array}{l}\text { Condorelli et } \\
a l ., 2018\end{array}$ \\
\hline \multirow[t]{2}{*}{ Sorghum } & $\begin{array}{l}\text { Drought } \\
\text { stress }\end{array}$ & $\begin{array}{l}\text { Unmanned ariel vehicle } \\
\text { imagery }\end{array}$ & $\begin{array}{l}\text { Stay green values, NDVI } \\
\text { values, values, leaf senescence } \\
\text { and canopy traits }\end{array}$ & 427 hybrids & $\begin{array}{l}\text { Liedtke et al., } \\
2020\end{array}$ \\
\hline & $\begin{array}{l}\text { Drought } \\
\text { stress }\end{array}$ & $\begin{array}{l}\text { Imaging box with two } \\
\text { digital cameras using } \\
\text { Grow SCREEN Rhizo, } \\
\text { Win RHIZO Pro }\end{array}$ & Nodal root angle & $\begin{array}{l}976 \text { BC-NAM } \\
\text { progenies }\end{array}$ & Joshi et al., 2017 \\
\hline
\end{tabular}

\section{Conclusion}

To tackle the challenges of global climate change, development of climate-smart germplasm would be a priority to cope up with the abiotic stresses. High-throughput phenotyping for abiotic stress coupled with the advanced genotyping technologies and other phenomic technologies like transcriptomics and metabolomics have accelerated the process of developing stress resilient crops and thus cater the needs of global food challenge with respect to the changing climatic conditions and increasing population.

\section{Conflict of Interest}

Authors declare that they have no conflict of interest.

\section{Ethical Compliance Statement}

NA

\section{Author Contribution}

Conceptualization: SHW, ZAD; Initial Draft: NUI, SHW, GA; Critical review and finalization: AL, AW, SHW, ZAD 


\section{References}

1. Abdelhakim LO, E Rosenqvist, B Wollenweber, I Spyroglou, CO Ottosen and K Panzarová. 2021. Investigating Combined Drought-and Heat Stress Effects in Wheat under Controlled Conditions by Dynamic Image-Based Phenotyping. Agronomy. 11(2):364.

2. Araus JL and JE Cairns. 2014. Field high-throughput phenotyping: the new crop breeding frontier. Trends in Plant Science 19(1):52-61.

3. Atif RM, L Shahid, M Waqas, B Ali, MA Rashid, F Azeem, MA Nawaz, SH Wani and G Chung. Insights on calcium-dependent protein kinases (CPKs) signaling for abiotic stress tolerance in plants. International Journal of Molecular Sciences 20(21):5298.

4. Azhar MT, SH Wani, MT Chaudhary, T Jameel, P Kaur and X Du. 2020. Heat Tolerance in Cotton: Morphological, Physiological, and Genetic Perspectives. In: Azhar and Wani Eds. Heat Stress Tolerance in Plants: Physiological, Molecular and Genetic Perspectives. Academic Press 23:1-22.

5. Badigannavar A, N Teme, AC de Oliveira, G Li, M Vaksmann, VE Viana, TR Ganapathi and F Sarsu. 2018. Physiological, genetic and molecular basis of drought resilience in sorghum [Sorghum bicolor (L.) Moench]. Indian Journal of Plant Physiology 23(4):67088.

6. Berni JAJ, PJZ Tejada, L Suarez and E Fereres. 2009. Thermal and narrowband multispectral remote sensing for vegetation monitoring from an unmanned aerial vehicle IEEE Transanctions on Geoscience and Remote Sensing 47:722-738.

7. Billiau K, H Sprenger, C Schudoma, D Walther and KI Kohl. 2012. Data management pipeline for plant phenotyping in a multisite project. Functional Plant Biology 39:948-957.

8. Biskup B, H, Scharr, U Schurr and U Rascher. 2007. A stereo-imaging system for measuring structural parameters of plant canopies. Plant Cell and Environment 10:1299-1308.

9. Blancon J, D Dutartre, MH Tixier, M Weiss, A Comar, S Praud and F Baret. 2019. A high-throughput model-assisted method for phenotyping maize greenleaf area index dynamics using unmanned aerial vehicle imagery. Front Plant Sciences 10:685.

10. Bock CH, GH Poole, PE Parker and TR Gottwald. 2010. Plant disease severity estimated visually, by digital photography and image analysis and by hyperspectral imaging. Critical Reviews in Plant Sciences 29:59-107.

11. Buhler U, G Huber, F Schmid and P Blumler. 2011. Analytical model for long-distance tracer- transport in plants Journal of Theoretical Biology 270:70-79.

12. Bylesjo M, V Segura, RY Soolanayakanahally, AM Rae, J Trygg, P Gustafsson, S Jansson and NR Street. 2008. LAMINA: a tool for rapid quantification of leaf size and shape parameters. BMC Plant Biology 8:8-82.

13. Cattivelli L, F Rizza, FW Badeck, E Mazzucotelli, AM Mastrangelo, E Francia, C Mare, A Tondelli and AM Stanca. 2008. Drought tolerance improvement in crop plants: an integrated view from breeding to genomics. Field Crop Research 105:1-14.

14. Choudhary M, SH Wani, P Kumar, PK Bagaria, S Rakshit, M Roorkiwal and RK Varshney. 2019 QTLian breeding for climate resilience in cereals: progress and prospects. Functional $\mathcal{E}^{2}$ integrative Genomics. 19(5):685-701.

15. Close TJ, PR Bhat, S Lonardi, $\mathrm{YH} \mathrm{Wu}$ and $\mathrm{N}$ Rostoks. 2009. Development and implementation of high-throughput SNP genotyping in barley. $B M C$ Genomics 10:13.

16. Collins NC, F Tardieu and R Tuberosa. 2008. Quantitative trait loci and crop performance under abiotic stress: where do we stand? Plant Physiology 147:469-486.

17. Condorelli GE, M Maccaferri, M Newcomb, P Andrade-Sanchez, JW White, AN French and R Tuberosa. 2018. Comparative aerial and ground based high throughput phenotyping for the genetic dissection of NDVI as a proxy for drought adaptive traits in durum wheat. Frontiers in Plant Science 9:893.

18. Cook JP, MD McMullen, JB Holland, F Tian, P Bradbury, JR Ibarra, ES Buckler and S Garcia. 2012. Genetic architecture of maize kernel composition in 
the nested association mapping and inbred association panels. Plant Physiology 158:824-834.

19. Dale LM, A Thewis, C Boudry, I Rotar and V Baetan. 2013. Hyperspectral imaging applications in agriculture and agro-food quality and safety control: a review. Applied Spectroscopy Reviewes 48:142-159.

20. Dhont S, N Wuyts and D Inze. 2013. Cell to whole plant phenotyping: the best is yet to come. Trends in Plant Science 18:428-439.

21. Dissanayake R, HV Kahrood, AM Dimech, DM Noy, GM Rosewarne, KF Smith, NO Cogan and S Kaur. 2020. Development and Application of Image-Based High-Throughput Phenotyping Methodology for Salt Tolerance in Lentils. Agronomy 10(12): 1992.

22. Duan LF, WN Yang, CL Huang and Q Liu. 2011. A novel machine-vision- based facility for the automatic evaluation of yield-related traits in rice. Plant Methods 7:7-44

23. Enders TA, SS Dennis, S Oakland, ST Callen, EP Spalding, NM Springer and CD Hirsch. 2018. Classifying cold stress responses of inbred maize seedlings using RGB imaging. Plant Direct 23:1-11.

24. Fang S, X Yan and H Liao. 2009. 3D reconstruction and dynamic modeling of root architecture in situ and its application to crop phosphorus research. The Plant Journal 60:1096-1108.

25. Finkel E. 2009. With phenomics, plant scientists hope to shift breeding into Overdrive. Science 325:380-381.

26. Foulkes MJ, JW Snape, V Shearman, M P Reynold, O Gaju and R Sylvester-Bradley. 2007. Genetic progress in yield potential in wheat: recent advances and future prospects. Journal of Agricultural Science 145:17-29.

27. Furbank R T .2009. Plant phenomics: from gene to form and function. Functional Plant Biology 36:10-11.

28. Furbank R T and M Tester. 2011. Phenomicstechnologies to relieve the phenotyping bottleneck. Trends in Plant Science 16:635-644.

29. Ganie SA, S H Wani, R Henry and G Hensel. 2021. Improving rice salt tolerance by precision breeding in a new era. Current Opinion in Plant Biology 60:101996.

30. Ge Y, G Bai, V Stoerger and J C Schnable. 2016. Temporal dynamics of maize plant growth, water use, and leaf water content using automated high throughput RGB and hyperspectralimaging. Computers and Electronics in Agriculture 127:625-632.

31. Gerke J, K Lorenz and B Cohen. 2009. Genetic interactions between transcription factors cause natural variation in yeast. Science 323:498-501.

32. Golzarian M R, R A Frick, K Rajendran, B Berger, S Roy, M Tester and D S Lun. 2011. Accurate inference of shoot biomass from high-throughput images of cereal plants. Plant Methods 7:2-7.

33. Gosal SS, D Pathak, SH Wani, S Vij and M Pathak. 2020. Accelerated Breeding of Plants: Methods and Applications. In: Gosal, et al. eds.) Accelerated Plant Breeding, Volume 1 Springer, Cham. pp 1-29).

34. Haberland J A, P D Colaizzi, M A Kostrzewski, P M Waller, C Y Choi, F E Eaton, E M Barnes and T R Clarke. 2010. Agricultural Irrigation Imaging System. Applied Engineering in Agriculture 26:247-253

35. Hillnhutter C, R A Sikora, E C Oerke and D Dusschoten. 2012. Nuclear magnetic resonance: a tool for imaging belowground damage caused by Heteroderaschachtii and Rhizoctoniasolanion sugar beet. Journal of Experimental Botany 63:319-327.

36. Honsdorf N, T J March, B Berger, M Tester and K Pillen . 2014. High-throughput phenotyping to detect drought tolerance QTL in wild barley introgression lines. PloS one 9(5):97047.

37. Hu Y, S Knapp and U Schmidhalter. 2020. Advancing high-throughput phenotyping of wheat in early selection cycles. Remote Sensing 12(3):574.

38. Ikeda M, Y Hirose, T Takashi, Y Shibata, T Yamamura, T Komura, K Doi, M Ashikari, M Matsuoka and H Kitano. 2010. Analysis of rice panicle traits and detection of QTLs using an image analyzing method. Breeding Science 60:55-64.

39. Itam M, R Mega, S Tadano, M Abdelrahman, S Matsunaga, Y Yamasaki, K Akashi and H Tsujimoto. 2020. Metabolic and physiological responses to progressive drought stress in bread wheat. Scientific Reports 10(1):1-4.

40. Jagadish, SK, RN Bahuguna, M Djanaguiraman, R Gamuyao, PV Prasad and PQ Craufurd. 2016. Implications of high temperature and elevated 
CO2on flowering time in plants. Frontiers in Plant Science 7:913.

41. Jahnke, S, MI Menzel, D Dusschoten, GW Roeb, J Buhler, S Minwuyelet, P Blumle, VM Temperton, T Hombach and M. Streun. 2009. Combined MRIPET dissects dynamic changes in plant structures and functions. The Plant Journal 59:634-644.

42. James RA and XR Sirault. 2012. Infrared thermography in plant phenotyping for salinity tolerance. Methods in Molecular Biology 913:173-189.

43. Jansen M, F Gilmer, B Biskup, KA Nagel, U Rascher, A Fischbach, S Briem, G Dreissen, S Tittmann and S Braun. 2009. Simultaneous phenotyping of leaf growth and chlorophyll fluorescence via GROWSCREEN FLUORO allows detection of stress tolerance in Arabidopsis thaliana and other rosette plants. Functional Plant Biology 36:902-914.

44. Jensen T, A Apan, F Young and L Zeller. 2007. Detecting the attributes of a wheat crop using digital imagery acquired from a low-altitude platform. Computers and Electronics in Agriculture 59:66-77.

45. Jones HG, R Serraj, BR Loveys, L Xiong, A Wheaton and A H Price. 2009. Thermal infrared imaging of crop canopies for the remote diagnosis and quantification of plant responses to water stress in the field. Functional Plant Biology 36:978-989.

46. Joshi DC, V Singh, C Hunt, E Mace, E Van Oosterom, R Sulman and G Hammer. 2017. Development of a phenotyping platform for high throughput screening of nodal root angle in sorghum. Plant Methods 13(1): 1-12.

47. Kamal NM, YS Gorafi, M Abdelrahman, E Abdellatef and H Tsujimoto. 2019. Stay-green trait: A prospective approach for yield potential, and drought and heat stress adaptation in globally important cereals. International Journal of Molecular Sciences 20(23):5837.

48. Kastberger G and R Stachl. 2003. Infrared imaging technology and biological applications. Behaviour Research Methods, Instruments and Computers 35:429439.

49. Khadka K, HJ Earl, MN Raizada and A Navabi. 2020. A physio-morphological trait-based approach for breeding drought tolerant wheat. Frontiers in Plant Science 11:715.
50. Kim S L, N Kim, H Lee, E Lee, K S Cheon, M Kim and K H Kim. 2020. High-throughput phenotyping platform for analyzing drought tolerance in rice. Planta 252(3):1-18.

51. Kiyomiya S, H Nakanishi, H Uchida, A Tsuji, S Nishiyama, M Futatsubashi, N S Ishioka, S Watanabe and T Ito. 2011. Real time visualization of $13 \mathrm{~N}$-translocation in rice under different environmental conditions using positron emitting tracer imaging system. Plant Physiology 125: 1743-1753.

52. Krajewski P, D Chen and Ćwiek H. 2015. Towards recommendations for metadata and data handling in plant phenotyping. Journal of Experimental Botany 66: 5417-5427.

53. Kumar N, M Rana, B Kumar, S Chand, A Shiv, S H Wani and S Kumar. 2021. Genomic Selection for Wheat Improvement. In: Wani et al., eds. Physiological, Molecular, and Genetic Perspectives of Wheat Improvement. Springer Switzerland. 175-207.

54. Kumar M, A Mahato, S Kumar and VK Mishra.2020. Phenomics-Assisted Breeding: An Emerging Way for Stress Management. In New Frontiers in Stress Management for Durable Agriculture, Springer, Singapore. pp. 295-310

55. Lafitte R, A Blum and G Atlin. 2003. Using secondary traits to help identify drought-tolerant genotypes In: Fischer KS, Lafitte R, Fukai S, Atlin G, Hardy B (eds) Breeding rice for drought-prone environments International Rice Research Institute, Los Banos.

56. Leakey A D, E A Ainsworth, C J Bernacchi, A Rogers, S P Long and D R Ort. 2009. Elevated CO2 effects on plant carbon, nitrogen, and water relations: six important lessons from FACE. Journal of Experimental Botany 60: 2859-2876.

57. Leinonen I and Jones H G. 2004. Combining thermal and visible imagery for estimating canopy temperature and identifying plant stress. Journal of Experimental Botany 55: 1423-1431.

58. Lichtenthaler H K. 1996. Detection of vegetation stress via a new high resolution fluorescence imaging system. Journal of Plant Physiology 148: 599-612.

59. Liedtke J D, C H Hunt, B George-Jaeggli, K Laws, J Watson, A B Potgieter and D R Jordan. 2020. Highthroughput phenotyping of dynamic canopy traits 
associated with stay-green in grain sorghum. European Journal of Agronomy 35: 22-32.

60. Li Y, W Wen, X Guo, Z Yu, S Gu, H Yan and C Zhao. 2021. High-throughput phenotyping analysis of maize at the seedling stage using end-to-end segmentation network. Plos One. 16(1): e 0241528.

61. Liu J, Tchen and H Wang. 2021. The miR172/IDS1 signaling module confers salt tolerance through maintaining ROS homeostasis in cereal crops. New Phytologist 230(3):1017-1033

62. Lobet G, L Pages and X Draye. 2011.A novel imageanalysis toolbox enabling quantitative analysis of root system architecture. Plant Physiology 157: 29-39.

63. Maphosa L, E Thoday-Kennedy, J Vakani, A Phelan, P Badenhorst, A Slater and S Kant. 2017. Phenotyping wheat under salt stress conditions using a 3D laser scanner. Israel Journal of Plant Sciences 64(3-4): 55-62.

64. Meroni M, M Rossini, L Guanter, L Alonso, U Rascher, R Colombo and J Moreno. 2009. Remote sensing of solar induced chlorophyll fluorescence: review of methods and applications. Remote Sensing of Environment 113: 2037-2051.

65. Mertens T, L Verbraeken, H Sprenger, K Demuynck, K Maleux, B Cannoot and N Wuyts. 2021. Proximal Hyperspectral Imaging Detects Diurnal and DroughtInduced Changes in Maize Physiology. Frontiers in Plant Science 12: 640914.

66. Mickelbart M V, P M Hasegawa and J Bailey-Serres. 2015. Genetic mechanisms of abiotic stress tolerance that translate to crop yield stability. Nature Revieres Genetics 16: 237-251.

67. Mikołajczak K, P Ogrodowicz, H Ćwiek-Kupczyńska, K Weigelt-Fischer, S R Mothukuri, A Junker and P Krajewski. 2020. Image Phenotyping of Spring Barley (Hordeum vulgare L.) RIL Population Under Drought: Selection of Traits and Biological Interpretation. Frontiers in Plant Science 11: 743.

68. Mir R R, Z Mainassara, R Sreenivasulu, K Rajeev and T Varshney. 2012. Integrated genomics, physiology and breeding approaches for improving drought tolerance in crops. Theoretical and Applied Genetics 125: 625-645.
69. Moller M, V Alchanatis, Y Cohen, M Meron, J Tsipris, A Naor, V Ostrovsky, M Sprintsin and S Cohen. 2007. Use of thermal and visible imagery for estimating crop water status of irrigated grapevine. Journal of Experimental Botany 58: 827-838.

70. Montes J M, A E Melchinger and J C Reif. 2007. Novel throughput phenotyping platforms in plant genetic studies. Trends in Plant Science 12: 433-436.

71. Munns R and M Tester. 2008.Mechanisms of salinity tolerance. Annual Review of Plant Biology 59: 651-681.

72. Nainanayake, A D. 2007. Use of chlorophyll fluorescence parameters to assess drought tolerance of coconut varieties. Cocos 18: 77-105.

73. Negin B, M Moshelion M. 2017. The advantages of functional phenotyping in pre-field screening for drought-tolerant crops. Functional Plant Biology 25,44(1):107-18.

74. O’Toole J C and T T Chang. 1979. Drought resistance in cereals: a case study In: Mussell H, Staples RC. Stress Physiology in Crop Plants 23: 67-78.

75. OmasaK, F Hosoi and A Konishi. 2007. 3D LIDAR imaging for detecting and understanding plant responses and canopy structure. Journal of Experimental Botany 58: 881-898.

76. Paproki A, X Sirault, S Berry, R Furbank and J Fripp. 2012. A novel mesh processing-based technique for 3D plant analysis. BMC Plant Biology 12: 63-71.

77. Pascuzzi A S, O Symonova, Y Mileyko, Y Hao, H Belcher, J Harer, J S Weitz and P N Benfey. 2010. Imaging and analysis platform for automatic phenotyping and trait ranking of plant root systems. Plant Physiology 152: 1148-1157.

78. Pereira A. 2016. Plant abiotic stress challenges from the changing environment. Frontiers in Plant Science 7: 1123 .

79. Perret J S, M E Al-Belushi and M Deadman. 2007. Non- destructive visualization and quantification of roots using computed tomography. Soil Biology and Biochemistry 39: 391-399.

80. Pineda M, M, Barón, and M L Pérez-Bueno. 2021. Thermal Imaging for Plant Stress Detection and Phenotyping. Remote Sensing 13(1): 68. 
81. Rajendran K, M Tester and SJ Roy 2009. Quantifying the three main components of salinity tolerance in cereals. Plant Cell and Environment 32: 237-249.

82. Reddy T Y, V R Reddy and V Anbumozhi. 2003. Physiological responses of groundnut (Arachis hypogea L.) to drought stress and its amelioration: a critical review. Plant Growth Regulation 41: 75-88.

83. Ritchie G L, D G Sullivan, C D Perry, J E Hook and C W Bednarz. 2008. Preparation of a low-cost digital camera system for remote sensing. Applied Engineering in Agriculture 24: 885-896.

84. Romano G, S Zia, W Spreer, C Sanchez, J Cairns, J L Araus and J Müller. 2011. Use of thermography for high throughput phenotyping of tropical maize adaptation in water stress. Computers and Electronics in Agriculture 79(1): 67-74.

85. RutkoskiJ,J Poland, S Mondal, E Autrique, L González Párez and J Crossa. 2016.Canopy temperature and vegetation indices from high-throughput phenotyping improve accuracy of pedigree and genomic selection for grain yield in wheat. G3 Genes Genomes Genetics $6: 1-36$.

86. Saade S D, C Brien, M Shahid, J Russell, R Waugh, S Negrão and Tester M. 2020. Dissecting new genetic components of salinity Tolerance in two-row spring barley at the Vegetative and reproductive stages. PLOS ONE 5(7): 0236037.

87. Sallam A, A Amro, EA Ammar, MF Dawood, T Kumamaru and PS Baenziger. 2018. Genetic diversity and genetic variation in morpho-physiological traits to improve heat tolerance in Spring barley. Molecular Biology Reports 45(6):2441-53.

88. Schmidt J, J Claussen, N Wörlein, A Eggert, D Fleury, T Garnett and S Gerth. 2020. Drought and heat stress tolerance screening in wheat using computed tomography. Plant Methods 16:15.

89. Seelig H D, A Hoehn and L S Stodieck. 2008.The assessment of leaf water content using leaf refectance ratios in the visible, near-, and short-wave-infrared. International Journal of Remote Sensing 29:3701-3713.

90. Shakoor N, S Lee and TC Mockler. 2017. High throughput phenotyping to accelerate crop breeding and monitoring of diseases in the field. Current Opinion in Plant Biology 238:184-92.
91. Shibayama M, T Sakamoto, E Takada, A Inoue, K Morita, T Yamaguchi, W Takahashi and A Kimura. 2011. Regression-based models to predict rice leaf area index using biennial fixed point continuous observations of near infrared digital images. Plant Production Science 14: 365-376.

92. Siddiqui Z S, J I Cho, S H Park, T R K Won, B O Ahn, G S Lee and S C Park. 2014. Phenotyping of rice in salt stress environment using high-throughput infrared imaging. Acta Botanica Croatica 73(1):149-158.

93. Siddiqui ZS, M Umar, TR Kwon and SC Park. 2019. Phenotyping through infrared thermography in stress environment. In Sabkha Ecosystems. Springer, Cham. pp. 239-251

94. Singh RK, A Prasad and M Prasad. 2020. Protein Phosphatases of Cereals and Millets: Identification, Structural Organization, and Their Involvement in the Regulation of Abiotic Stresses. In: Protein Phosphatases and Stress Management in Plants, Springer, Cham. pp. 245-260

95. Sirault X R, James R A and R T Furbank. 2009. A new screening method for osmotic component of salinity tolerance in cereals using infrared thermography. Functional Plant Biology 36: 970-977.

96. Song P, J Wang, X Guo, W Yang and C Zhao.2021. High-throughput phenotyping: breaking through the bottleneck in future crop breeding. The Crop Journal https://doi.org/10.1016/j.cj.2021.03.015

97. Su Y, F Wu, S Jin, T Hu, S Pang, L Liu and Q Guo. 2019. Evaluating maize phenotype dynamics under drought stress using lidar-based field high-throughput phenotyping system. Plant Methods 15:11.

98. Tamimi N A, C Brien, H Oakey, B Berger and M Tester. 2016.Salinity tolerance loci revealed in rice using high-throughput non-invasive phenotyping. Nature Communications 7:13342.

99. Tejada ZPJ, JAJ Berni, L Subrez, G Sepulcre-Canto, F Morales and JR Miller. 2009. Imaging chlorophyll fluorescence with an airborne narrow-band multispectral camera for vegetation stress detection. Remote Sensing of Environment 113: 1262-1275.

100. Tester M and P Langridge. 2010.Breeding technologies to increase crop production in a changing world. Science 327: 818-822. 
101. Topp C N, S I Anjali and J T Anderson. 2013. 3D phenotyping and quantitative trait locus mapping identify core regions of the rice genome controlling root architecture. PANAS 110: 1695-1704.

102. Tsukamoto T, H Nakanishi, H Uchida, S Watanabe, S Matsuhashi, S Mori and N K Nishizawa. 2009. ${ }^{52} \mathrm{Fe}$ translocation in barley as monitored by a PositronEmitting Tracer Imaging System (PETIS): evidence for the direct translocation of Fe from roots to young leaves via phloem. Plant Cell Physiology 50: 48-57.

103. Van H. 2007. Intact plant MRI for the study of cell water relations, membrane permeability, cell-tocell and long-distance water transport. Journal of Experimental Botany 58: 743-756.

104. Vandenbroucke K and M Metzlaff. 2013. Abiotic stress tolerant crops: genes, pathways and bottlenecks. Encyclopedia of Sustainability Science and Technology 10: 1-3.

105. Varshney RK, JM Ribaut, ES Buckler, R Tuberosa, JA Rafalski and P Langridge. 2012. Can genomics boost productivity of orphan crops. Nature Biotechnology 30 : 1172-1176.

106. Varshney R K, R Terauchi and S R McCouch. 2014. Harvesting the Promising Fruits of Genomics: Applying Genome Sequencing Technologies to Crop Breeding. PLOS Biology 13: 528-530.

107. Vasseur F, T Bontpart, M Dauzat, C Granier and D Vil. 2014. Multivariate genetic analysis of plant responses to water deficit and high temperature revealed contrasting adaptive strategies. Journal of Experimental Botany 65: 6457-6469.

108. Wang $\mathrm{H}$ and A Yamauchi. 2006. Growth and function of roots under abiotic stress in soil. In: Huang B Plant environment interactions, 3rd edn CRC Press, New York.

109. Wang H, L Shabala, M Zhou and S Shabala. 2019. Developing a high-throughput phenotyping method for oxidative stress tolerance in barley roots. Plant methods 15(1): 1-9.

110. Wang Y, G Holroyd, A M Hetherington and C K Y Ng. 2004. Seeing 'cool' and 'hot'-infrared thermography as a tool for noninvasive, high-throughput screening of Arabidopsis guard cell signalling mutants. Journal of Experimental Botany 55: 1187-1193.
111. Wang Y, LA Graham, Z Han, R Eves, AK Gruneberg, RL Campbell, H Zhang and PL Davies.2020. Carrot 'antifreeze'protein has an irregular ice-binding site that confers weak freezing point depression but strong inhibition of ice recrystallization. Biochemical Journal 477(12):2179-92.

112. Wani S H, S K Sah, G Sanghera, W Hussain and N B Singh. 2016. Genetic engineering for cold stress tolerance in crop plants In: Rahman, A (Ed). Advances in Genome Science: Genes in Health and Disease, Bentham Science Publishers, UAE pp. 173-201

113. Wani SH, JR Choudhary, M Choudhary, M Rana and SS Gosal SS. 2020b Recent advances in genomics assisted breeding for drought stress tolerance in major cereals. Journal of Cereal Research 12(1): 1-12.

114. Wani SH, P Tripathi, A Zaid, GS Challa, A Kumar, V Kumar, J Upadhyay, R Joshi and M Bhatt. 2018. Transcriptional regulation of osmotic stress tolerance in wheat (Triticum aestivum L.). Plant Molecular Biology 97(6):469-87.

115. Wani SH, S Anand, B Singh, A Bohra and R Joshi. 2021. WRKY transcription factors and plant defense responses: latest discoveries and future prospects. Plant Cell Reports 15:1-5.

116. Wani SH, V Kumar, T Khare, P Tripathi, T Shah, C Ramakrishna, S Aglawe and SK Mangrauthia. 2020a. miRNA applications for engineering abiotic stress tolerance in plants. Biologia 75(7):1063-81.

117. Wani SH. 2019. Recent Approaches in Omics for Plant Resilience to Climate Change. Springer Nature, Switzerland.

118. Watanabe T, J S Hanan, P M Room, T Hasegawa, H Nakagawa and W Takahashi. 2005. Rice morphogenesis and plant architecture: measurement, specification and the reconstruction of structural development by 3D architectural modeling. Annals of Botany 95: 1131-1143.

119. Weirman, A. 2010. Plant phenomics teacher resource http://www plantphenomics org au/files/teacher/ Final_Phenomics_for_word_with_images doc Accessed on 7 May 2013.

120. White J W, P Andrade, M A Gore, K F Bronson, A N French, B A Kimball, RJ Strand, K R Thorp and 
High-throughput Phenotyping for Abiotic Stress Resilience in Cereals

G W Wall. 2012. Field-based phenomics for plant genetics. Field Crops Research 133: 101-112.

121. Windt C, W F Vergeldt, P A Jager, and A H Van. 2006. MRI of long-distance water transport: a comparison of the phloem and xylem flow characteristics and dynamics in poplar, castor bean, tomato and tobacco. Plant Cell and Environment 29: 1715-1729.

122. Woo N S, M R Badger and B J Pogson. 2008. A rapid, non- invasive procedure for quantitative assessment of drought survival using chlorophyll fluorescence. Plant Methods 4: 27-34.

123.Xie C, C Yang and A Moghimi. 2017. Detection of cold stressed maize seedlings for high throughput phenotyping using hyperspectral imagery. In Hyperspectral Imaging Sensors: Innovative Applications and Sensor Standards 10213:1021305). International Society for Optics and Photonics.

124. Xie Y, C Wang, W Yang, M Feng, X Qiao and J Song. 2020. Canopy hyperspectral characteristics and yield estimation of winter wheat (Triticum aestivum) under low temperature injury. Scientific Reports 10(1):1-10.

125. Yang W, L Duan, G Chen, L Xiong and Q Liu. 2013. Plant phenomics and high-throughput phenotyping: accelerating rice functional genomics using multidisciplinary technologies. Current Opinion in Plant Biology 16:1-8.

126. Yang W, Z Guo and C Huang. 2015. Genome-wide association study of rice (Oryza sativa L.) leaf traits with a high-throughput leaf score Journal of Experimental Botany 66:5605-5615.

127. Yang W, H Feng, X Zhang, J Zhang, JH Doonan, WD Batchelor, L Xiong and J Yan. 2020. Crop phenomics and high-throughput phenotyping: past decades, current challenges, and future perspectives. Molecular Plant 13(2):187-214.

128. Yendrek C R, T Tomaz, C M Montes, Y Cao, A M Morse, P J Brown, M L McIntyre, A B Leakey and E A Ainsworth. 2017. High-Throughput Phenotyping of Maize Leaf Physiological and Biochemical Traits Using Hyperspectral Reflectance. Plant Physiology 17: 614-626.

129.Ziska L H and J A Bunce. 2007. Predicting the impact of changing $\mathrm{CO} 2$ on crop yields: some thoughts on food. New Phytologist 175: 607-618. 